\title{
Influence of Bacteria on Compressive Strength of Rubber Mould Paver Block
}

\author{
Maulik Sharma ${ }^{1}$, Dr. Jayeshkumar Pitroda ${ }^{2}$, Dr. Digvijaysinh Rana ${ }^{3}$ \\ ${ }^{1}$ Finalyear M. Tech. Student, Construction Engineering and Management, \\ B. V. M. Engineering College, V.V. Nagar, Gujarat, India \\ ${ }^{2}$ Assistant Professor, Civil Engineering Department, B. V. M. Engineering College, \\ V.V. Nagar, Gujarat, India \\ ${ }^{3}$ AssistantProfessor, ARIBAS, New Vallabh Vidyanagar, Gujarat, India
}

\begin{abstract}
The currently paver block is used in outdoor usefulness application and also it is used in path road and other Construction places. Paver block has low maintenance cost and without difficulty exchange with a newer one at the time of breakage. The quality of concrete used to make paver block may be the major issue, so that the strength of concrete paver block depends measuredly on quality of concrete. Thus an attempt present Research study, work, Rubber Mould Paver Block (RMPB) of M30 grade of $60 \mathrm{~mm}$ thickness light traffic with varying concentration cell/ml of Bacteria culture inclusion of Rubber Mould Paver Block (RMPB). There are lots of bacteria available, and certain of it can be used in the construction industry for development of the overall construction. Bacteria are used to increase compressive strength. So that type of Rubber Mould Paver Block $(R M P B)$ is cast. And finding optimum bacteria concentration cell/ml. To study the changes in compressive strength of Rubber Mould Paver Block (RMPB)by the inclusion of bacterial Rubber Mould Paver Block (RMPB) and without inclusion of bacterial Rubber Mould Paver Block (RMPB).
\end{abstract}

Keywords: Compressive Strength, Bacillus Pasteurii, Bacillus Cereus, Rubber Mould Paver Block (RMPB)

\section{INTRODUCTION}

Rubber mould Paver blocks are the recent solution for low cost outdoor application. Concrete Paver block is hard, unreinforced pre-cast cement concrete paving units used in the surface of the top layer road. They are high strength concrete precast components in various shapes, sizes and colours to suit the imagination of land architects and nature's essence. Through increasing its compressive strength it can be used in heavy traffic area also. Rubber mould paver blocks are manufactured concrete product that is independently located in a variety of arrangements and shapes as per the necessity. They do not absorb water and can be located so that surplus water is taken away from the lawn and court area rather than over-saturating it. This type of roadway will absorb stress, such as small earthquakes, freezes and thaws, and slight ground erosion by flexing. Therefore, they do not easily crack, break or buckle like pouring bitumen or poured concrete. Bacteria are used in the Rubber Mould Concrete Paver Block improves resistance to abrasion and enhance quality of construction. [5]

The rubber mould paver block is being accepted widely in different uses where the convectional construction of pavement using a hot bituminous mix or cement concrete work is not possible or required. Interlocking concrete block has been widely used in many countries for quite some time specific problem solving methods if pavement in areas where conventional types of construction are less durable to many operational and environmental limitations. A decade ago Interlocking paver block technology has been introduced to the construction production in India. [10]

Bacteria constitute a large domain of prokaryotic microorganisms. Typically a few micrometers in length, bacteria have a number of shapes, ranging from spheres to rods and spirals. Microbial mineral precipitation resulting from metabolic activities of favorable microorganisms in concrete improved the overall behavior of concrete. The process can occur inside or outside the microbial cell or even some distance away within the concrete. Often bacterial activities simply trigger a change in solution chemistry that leads to over saturation and mineral precipitation. Use of these Bio mineralogy concepts in concrete leads to the potential invention of new material called-Bacterial Concrete. [2] 


\section{EXPERimental MATERials}

Following are the experimental materials for the research experimental work

\subsection{Cement}

Cement basically acts as a binding material that holds all the other components of the block.The cement available in the local market (OPC) Cement 53 grades Conforming to IS 8112: 2009 is used.

\subsection{Coarse Aggregate}

Natural Crushed Stone conforming to IS: 383 (1987) was employed. Coarse aggregate of size $10 \mathrm{~mm}$ down having the specific gravity of 2.77 and fineness modulus of 5.732 was applied.

\subsection{Fine Aggregate}

The natural river sand available in the local market is used as a fine aggregate. The fine and coarse aggregates shall consist of crushed or uncrushed materials, which apart from the grading requirements comply with IS 383:1970. The fine aggregate (Sand) belongs to grading Zone II as per IS: 383-1970. Fineness Modulus of sand is 2.935. The specific gravity of fine aggregate is 2.55 .

\subsection{Water}

The water shall be clean and free from deleterious matter. It shall meet the requirements stipulated in IS 456:2000.

\subsection{Microorganism}

Following are two bacteria was used in experimental work

\subsubsection{Bacillus Pasteurii}

Bacillus species are aerobic, sporulating, rod-shaped bacteria that are ubiquitous in nature. Majority of Bacillus species is harmless. B. pasteurii, a common bacterium naturally occurring in the subsurface, is such an aerobic microorganism. Bacillus Pasteurii NCIM 2477 going to use for Rubber Mould Paver Block product. Bacillus are a type of bacteria that can produce calcium carbonate $\left(\mathrm{CaCO}_{3}\right)$ as a filler material and serve as a binding factor in concrete. Calcium carbonate $\left(\mathrm{CaCO}_{3}\right)$ can reduce capillary pores of concrete and improve durability and compressive strength. Bacillus Pasteurii is also known as Sporosarcina Pasteurii. [2]Figure 1 shows the Bacillus Pasteurii.

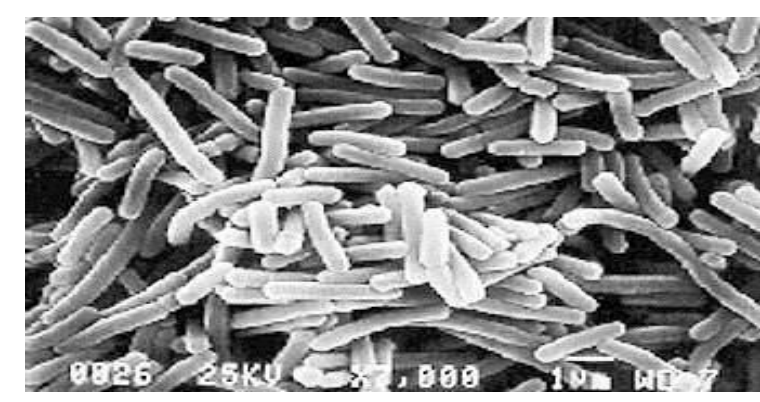

Figure1. Bacillus Pasteurii

(Source: http://lenta.ru/news/2007/03/07/stone/)

\subsubsection{Bacillus Cereus}

Bacillus cereus is gram-positive, rod -shaped, aerobic, motile, beta haemolyticbacterium commonly found in soil and food. Bacillus cereus going to use for Rubber Mould Paver Block.Figure 2 shows the Bacillus Cereus.

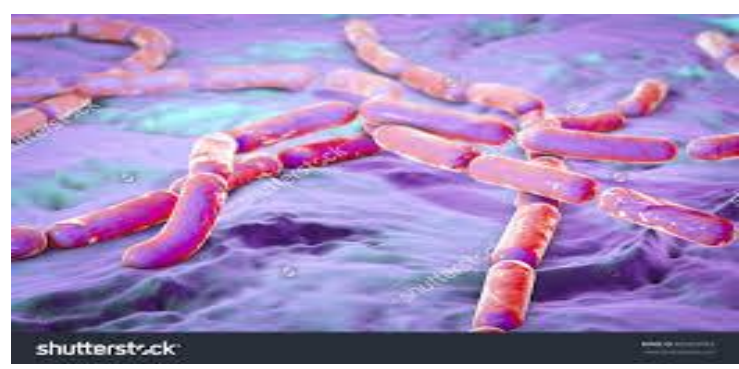

Figure2. Bacillus Cereus

(Source: http://lenta.ru/news/2007/03/08/stone/) 


\subsection{Other Additives}

Under special conditions, admixture at around 7 per cent of cement by weight is added for high early strength.

\section{DeSIGN MiX}

Design Mix of M30 Grade with 60 mm thick Rubber Mould Paver Block (IS: 456-2000, IRC: SP: 632004).As shown in Table 1 and same was used to prepare the various test samples inclusion of bacteria concentration cell $/ \mathrm{ml}$. The design mix proportion is shown in Table 2.

Table1. Design Mix of (M30 Grade) 60 Mm Thick Rubber Mould Paver Block (Is: 456-2000, Irc: Sp: 63-2004)

\begin{tabular}{|c|c|c|c|c|}
\hline Cement & F. A & C. A & Admixture & Water \\
\hline 410 & 685 & 1160 & 7 & 155 \\
\hline 1 & 1.67 & 2.83 & 0.017 & 0.38 \\
\hline
\end{tabular}

F. A. $=$ Fine Aggregate, C. A. = Coarse Aggregate

Table2. Inclusion of Bacteria Concentration Cell/Ml in Rubber Mould Paver Block

\begin{tabular}{|c|c|c|c|c|c|}
\hline $\begin{array}{c}\text { Sr. } \\
\text { No }\end{array}$ & Cement & $\begin{array}{c}\text { Bacteria } \\
\text { concentration } \\
\text { Cell/ml }\end{array}$ & F. A & C. A & $\begin{array}{c}\text { Admixture } \\
\text { (\%) }\end{array}$ \\
\hline A & 410 & 0 & 685 & 1160 & 7 \\
\hline B1 & 410 & $10^{5}$ & 685 & 1160 & 7 \\
\hline B2 & 410 & $10^{6}$ & 685 & 1160 & 7 \\
\hline B3 & 410 & $10^{7}$ & 685 & 1160 & 7 \\
\hline B4 & 410 & $10^{8}$ & 685 & 1160 & 7 \\
\hline B5 & 410 & $10^{9}$ & 685 & 1160 & 7 \\
\hline C1 & 410 & $10^{5}$ & 685 & 1160 & 7 \\
\hline C2 & 410 & $10^{6}$ & 685 & 1160 & 7 \\
\hline C3 & 410 & $10^{7}$ & 685 & 1160 & 7 \\
\hline C4 & 410 & $10^{8}$ & 685 & 1160 & 7 \\
\hline C5 & 410 & $10^{9}$ & 685 & 1160 & 7 \\
\hline
\end{tabular}

F. A. $=$ Fine Aggregate, C. A. $=$ Coarse Aggregate

Where, A is without inclusion bacterial Rubber Mould Paver Block, B1 to B5 is Bacillus Pasteurii bacterial Rubber Mould Paver Block and C1 to C5 is Bacillus Cereus bacterial Rubber Mould Paver Block

\section{EXPERIMENTAL Methodology}

\subsection{Testing Methodology}

Rubber Mould Paver Block concrete contains cement, fine aggregate, coarse aggregate, bacterial culture Distilled water and admixture is used in the Rubber Mould Paver Block. Bacterial culture Distilled water inclusion of the Rubber Mould Paver Block with a suitable concentration of bacteria, respectively $10^{5}, 10^{6}, 10^{7}, 10^{8}, 10^{9}$ cells $/ \mathrm{ml}$. For compression test there were four members of paver block has been cast. After about $24 \mathrm{~h}$ the specimens were placed at safe place and water curing was not needed. The respective specimens were tested after 7,14 and 28 days for compressive strength tests. [11]

\subsection{Compressive Strength Test Results [IS 15658:2006]}

Compressive strength tests were performed on compression testing machine using paver block samples. Four samples per batch were tested with the average strength values reported in this paper. The block has been stored in $24 \pm 4 \mathrm{~h}$ in water maintained at a temperature of $20 \pm 5^{\circ} \mathrm{C}$. The bearing plates of the testing machine shall be wiped clean. The specimens are aligned with those of the bearing plates. The load would be applied without shock and increased continuously at a rate of $15 \pm 3 \mathrm{~N} / \mathrm{mm}^{2} / \mathrm{min}$ until no greater load can be sustained by the specimen or delamination occurs. The maximum loads applied to the specimen were noted. [11]Figure 3 shows the setup of compressive strength testing machine. The compressive strength results are compiled in Table 3. 


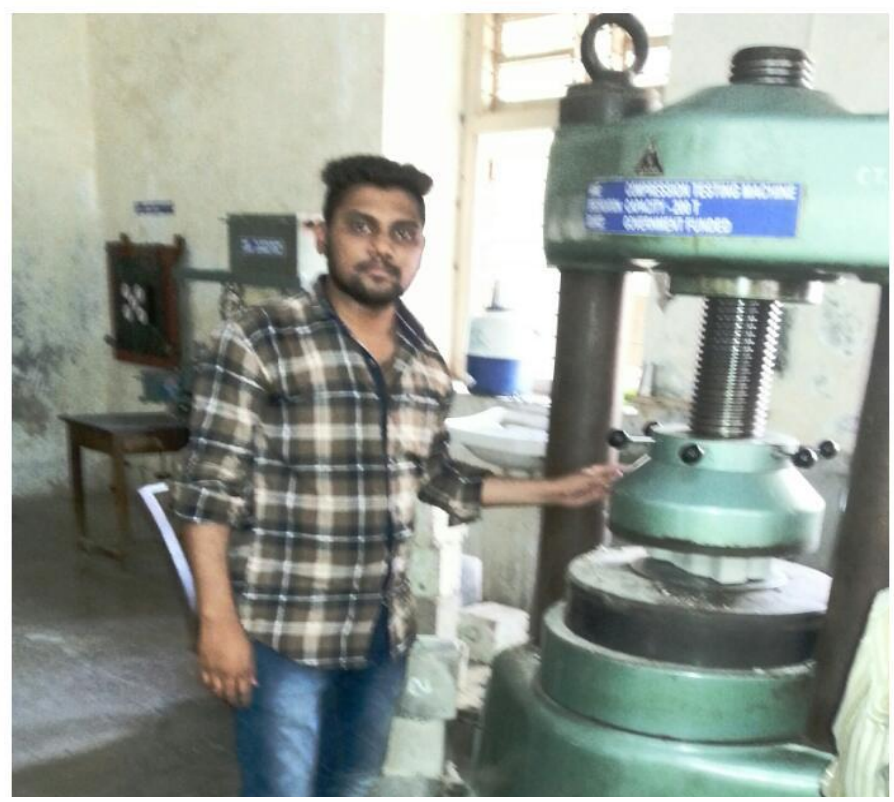

Figure3. Setup of Compression compressive strength testing machine

Table3. Comparative Experimental Results for Compressive Strength Test for M30 Mixes, Without Inclusion of Bacteria Rubber Mould Paver Block and With Inclusion of Bacteria Rubber Mould Paver Block.

\begin{tabular}{|c|c|c|c|c|}
\hline Description & $\begin{array}{c}\text { Rubber Mould } \\
\text { Paver Block } \\
\text { Mixes }\end{array}$ & \multicolumn{3}{|c|}{$\begin{array}{c}\text { Average } \\
\text { Compressive Strength } \\
\text { (N/mm } \mathbf{2}^{2}\end{array}$} \\
\cline { 3 - 5 } & & $\mathbf{7}$ days & $\mathbf{1 4}$ days & $\mathbf{2 8}$ days \\
\hline Without inclusion of bacterial RMPB & $\mathbf{A}$ & 20.80 & 25.27 & 39.64 \\
\hline \multirow{3}{*}{ Bacillus Pasteurii inclusion of } & $\mathbf{B 1}$ & 21.07 & 27.05 & 40.63 \\
\cline { 2 - 5 } & $\mathbf{B 2}$ & 22.77 & 28.21 & 42.68 \\
\cline { 2 - 5 } & $\mathbf{B 3}$ & 25.27 & 29.02 & 43.39 \\
\cline { 2 - 5 } & $\mathbf{B 4}$ & 24.11 & 27.41 & 41.16 \\
\cline { 2 - 5 } & $\mathbf{B 5}$ & 23.13 & 25.36 & 39.82 \\
\hline Bacillus Cereus inclusion of & $\mathbf{C 1}$ & 22.23 & 26.34 & 41.34 \\
\cline { 2 - 5 } & $\mathbf{C 2}$ & 23.93 & 29.02 & 43.30 \\
\cline { 2 - 5 } & $\mathbf{C 3}$ & 26.79 & 31.25 & 45.09 \\
\cline { 2 - 5 } & $\mathbf{C 4}$ & 25.09 & 28.39 & 44.11 \\
\cline { 2 - 5 } & $\mathbf{C 5}$ & 24.02 & 26.07 & 42.50 \\
\hline
\end{tabular}

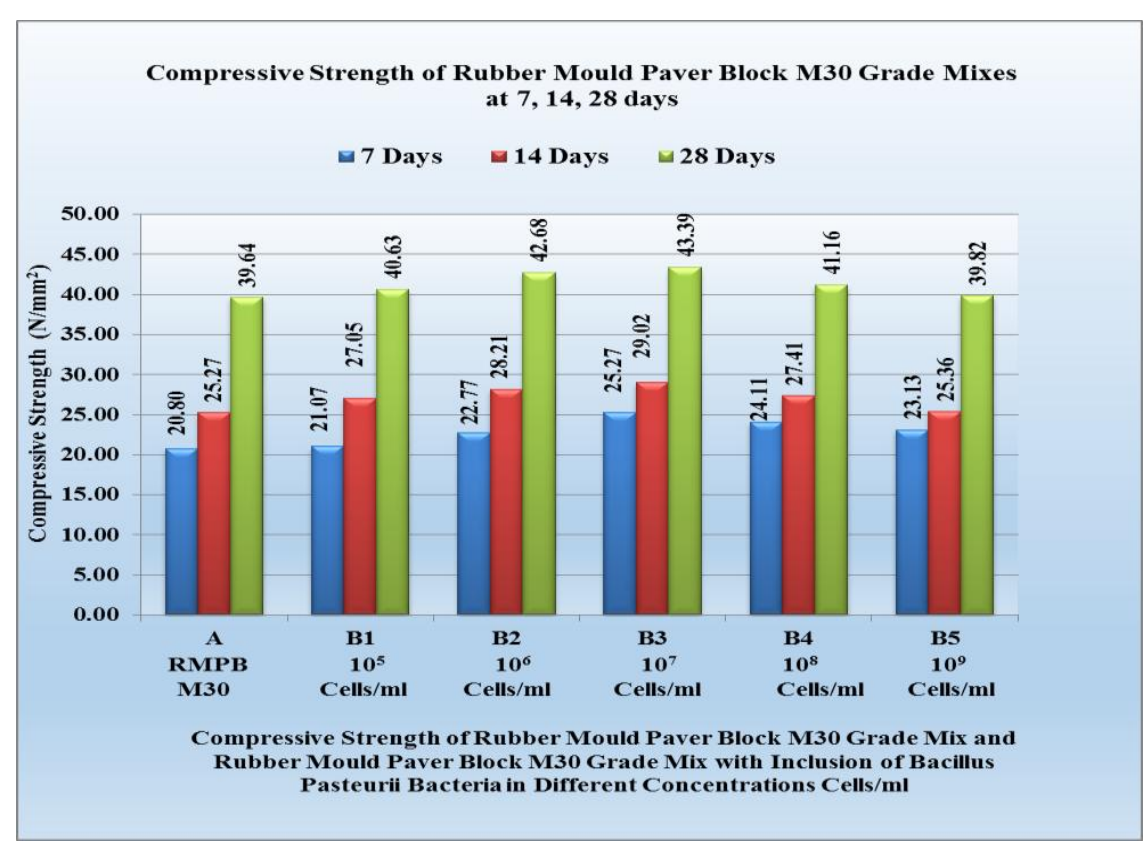

Figure4. Compressive Strength of Rubber Mould Paver Block M30 Grade Mix and Rubber Mould Paver Block M30 Grade Mix with Inclusion of Bacillus Pasteurii Bacteria in Different Concentrations Cells/ml 
From above figure 4, it can be said that the compressive strength of the M30 grade Rubber Mould paver Block mixes increased with increase in days. Also compressive strength increases with increase in bacterial content up to $10^{7}$ cells $/ \mathrm{ml}$ concentration, after it further increase in bacterial content decreases the compressive strength results, but it was higher than the without bacterial Rubber Mould paver Block mixes. So optimum bacterial content for maximum compressive strength was $10^{7}$ cells $/ \mathrm{ml}$ concentration. For $10^{7}$ cells $/ \mathrm{ml} \mathrm{B} 3$ mix shows $9.46 \%$ increase in compressive strength compare to without bacterial Rubber Mould paver Block (A) mix.

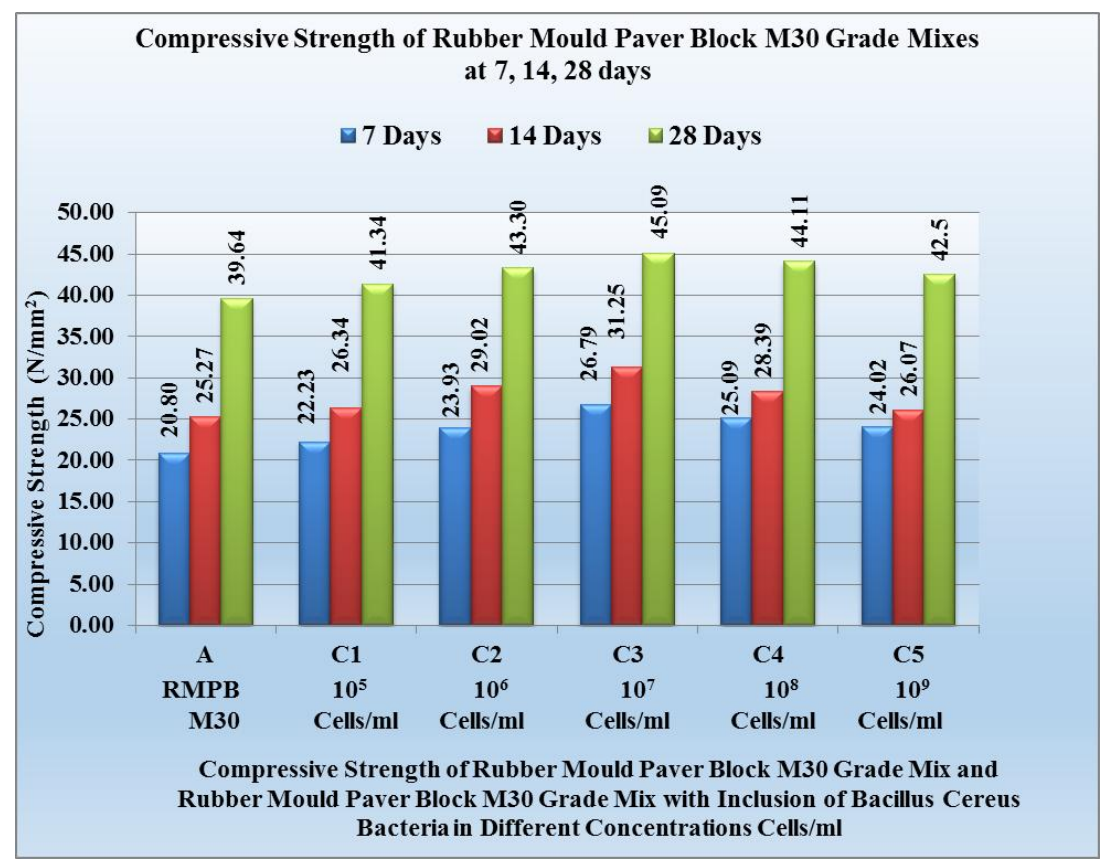

Figure5. Compressive Strength of Rubber Mould Paver Block M30 Grade Mix and Rubber Mould Paver Block M30 Grade Mix with Inclusion of Bacillus Cereus Bacteria in Different Concentrations Cells/ml

From above figure 5, it can be said that the compressive strength of the M30 grade Rubber Mould paver Block mixes increased with increase concentration cell $/ \mathrm{ml}$ in days. Also compressive strength increases with increase in bacterial content up to $10^{7}$ cells $/ \mathrm{ml}$ concentration, after it further increase in bacterial content decreases the compressive strength results, but it was higher than the without bacterial Rubber Mould paver Block mixes. So optimum bacterial content for maximum compressive strength was $10^{7}$ cells $/ \mathrm{ml}$ concentration. For $10^{7} \mathrm{cells} / \mathrm{ml} \mathrm{C} 3 \mathrm{mix}$ shows $\mathbf{1 3 . 7 4} \%$ increase in compressive strength compare to without bacterial Rubber Mould paver Block (A) mix.

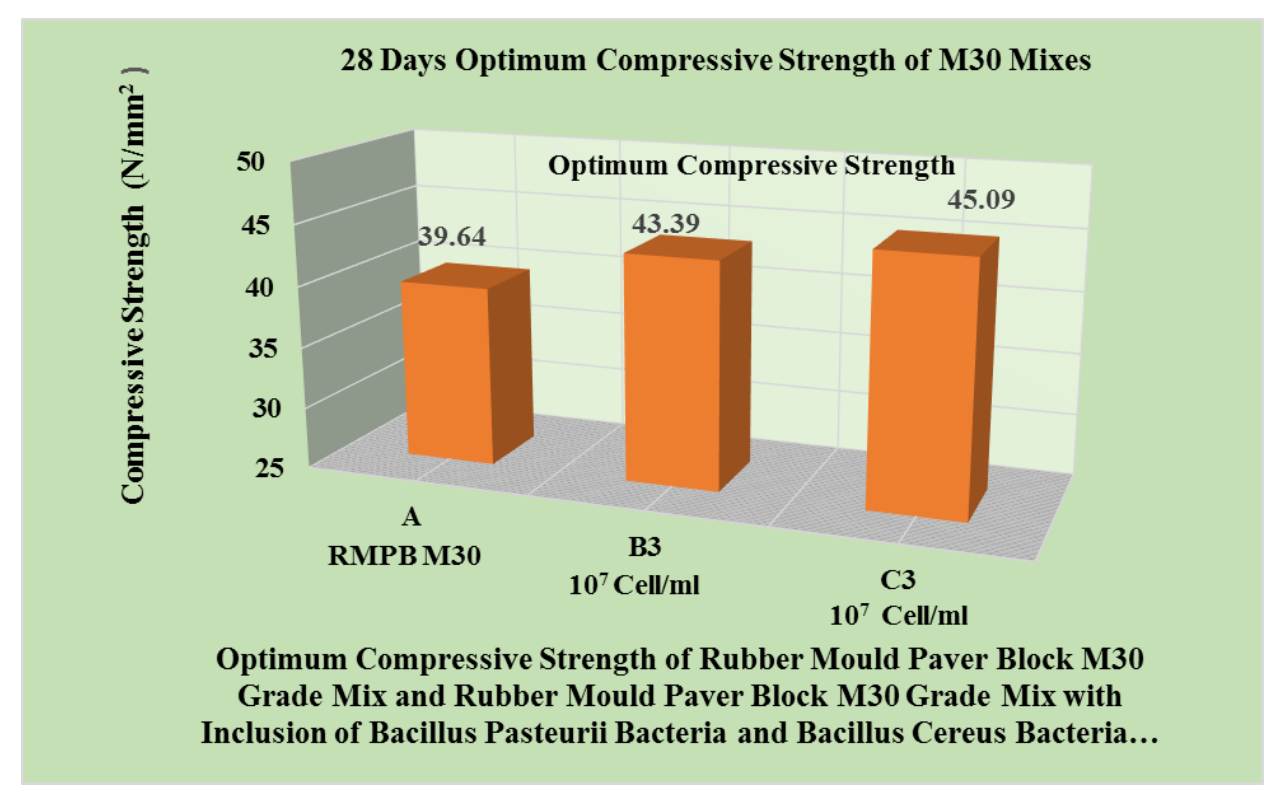

Figure6. Optimum Compressive Strength of Rubber Mould Paver Block M30 Grade Mix and Rubber Mould Paver Block M30 Grade Mix with Inclusion of Bacillus Pasteurii Bacteria and Bacillus Cereus Bacteria in Different Concentrations Cells/ml 
From above figure 6 . It can be shown that 28 days optimum compressive strength of M30 grade without bacterial Rubber Mould Paver Block (A mix), with the inclusion of Bacillus Pasteurii Bacterial Rubber Mould Paver Block (B3 mix) and inclusion of Bacillus Cereus Bacterial Rubber Mould Paver Block (C3 mix). So comparison of three types of the specimen at 28 days optimum compressive strength and concluded that maximum, optimum compressive strength of 28 days was $10^{7} \mathrm{cell} / \mathrm{ml} \mathrm{C} 3 \mathrm{mix}$. So Bacillus Cereus Bacteria given more compressive strength than B3 mix and (A) mix. Also Bacillus Pasteurii Bacteria given more compressive strength than (A) mix. Bacillus Cereus Bacterial Rubber Mould Paver Block ( $10^{7}$ cell $\left./ \mathrm{ml}\right) \mathrm{C} 3 \mathrm{mix}$ shows $\mathbf{3 . 9 2}$ \% increase in compressive strength compare to Bacillus Pasteurii Bacterial Rubber Mould Paver Block B3 mix.

\section{Conclusions}

From the above experimental test, following conclusion are drawn:

a) Compressive strength of Rubber Mould Paver Block (RMPB) increases after inclusion of bacillius pesturii and Bacillus Cereus bacteria in it.

b) Compressive strength increases as an increase in bacterial content up to $10^{7}$ cell/mlconcentration, further increase in bacterial content shows decrease in compressive strength of concrete.

c) For M30 grade of Rubber Mould Paver Block (RMPB), optimum mix is B3 and C3 with $10^{7}$ cell/ml concentration.

d) For M30 grade mix with inclusion of bacillius pesturii bacterial Rubber Mould Paver Block (RMPB) there was a $9.46 \%$ maximum increase in compressive strength compare to without bacterial Rubber Mould paver Block (A) M30 mix. And For M30 grade mix with the inclusion of Bacillus Cereus bacterialRubber Mould Paver Block (RMPB) there was a $13.74 \%$ maximum increase in compressive strength compare to without bacterial Rubber Mould paver Block (A) M30 mix.

e) Comparison in between them with the inclusion of Bacillus Cereusbacterial Rubber Mould Paver Block (RMPB) was Compressive strength more than with inclusion of bacillius pesturii bacterial Rubber Mould Paver Block (RMPB) and Without bacterial Rubber Mould paver Block (A) M30 mix.

\section{ACKNOWLEDGEMENT}

The authors thankfully acknowledge Prof (Dr.) Indrajit N. Patel, Principal, Birla Vishvakarma Mahavidyalaya Engineering College, Vallabh Vidyanagar, Prof (Dr.)L. B. Zala, Professor and Head of Department, Civil Engineering Department, Birla Vishvakarma Mahavidyalaya Engineering College, Vallabh Vidyanagar, Prof. J. J. Bhavsar, Associate Professor and PG Coordinator of Construction Engineering and Management, Civil Engineering Department, Birla Vishvakarma Mahavidyalaya Engineering College, Vallabh Vidyanagar for that motivations, infrastructural support and cooperation to carry out this research work.

\section{REFERENCES}

[1] Aaron D. V.,D’Souza D. N., Noothan K., Satish K.T.,Amar S.M., "Geopolymer Paver Blocks", Proc. of Int. Conf. on Advances in Civil Engineering July 2012

[2] Ardeshana A.B., Dr Pitroda J.R., Dr. Rana Digvijaysinh, "Improvement in Compressive Strength of Concrete By Inclusion of Bacillious Pesturi Bacteria" International Conference on: "Engineering: Issues, opportunities and Challenges for Development, ISBN: 978-81-929339-1-7, April, 2015

[3] Chahal N., Siddique R., Rajor A., "Influence of Bacteria on the Compressive Strength, Water Absorption and Rapid Chloride Permeability of Fly Ash Concrete" Construction And Building Materials 28 (2012) 351-356, October 2011

[4] Karasawa A., Suda S., Naito H., Fujiwara H., "Application of Fly Ash to Concrete Paving Block", Proceedings of the 7th International Conference on Concrete Block Paving (Pave Africa), ISBN Number: 0-958-46091-4, October 2003

[5] Kashiyani B K., Pitroda J, Shah B.K., "Effect of Polypropylene Fibers on Abrasion Resistance and Flexural Strength for Interlocking Paver Block", Internation Journal of Engineering and Trends and Technology (IJETT), ISSN: 2231-5381, Volume 4, Issue 5, May 2013 
[6] Kashiyani Bhavin K., Pitroda Jayeshkumar, Shah B. K. (2013), "A Study of Utilization Aspect of Polypropylene Fiber for Making Value Added Concrete, IJSR - International Journal of Scientific Research, Volume: 2, Issue: 2, ISSN No 2277 - 8179. , Feb 2013

[7] Kashiyani B K., Pitroda J, Shah B.K., "Innovative Addition of Polypropylene Fibre in Interlocking Paver Block to Improve Compressive Strength" International Journal of Civil, Structural, Environmental and Infrastructure Engineering Research and Development (IJCSEIERD) ISSN 2249-6866, Vol. 3, Issue 2, Jun 2013, 17-26

[8] Mall R., Shrama S., Patel R.D., " Studies of the Properties of Paver Block Using Fly Ash", International Journal For Scientific Research \& Development (IJSRD), ISSN (Online): 2321-0613, Vol. 2, Issue 10, 2014

[9] Mostafa S., Ali K. S., \& Aydin B., "Bioconcrete: Next Generation of Self-Healing Concrete", Appl Microbiol Biotechnol, January 2016

[10] Nataraja M. C., Das L., "A study on the Strength Properties of Paver Blocks made from Unconventional Materials", IOSR Journal of Mechanical and Civil Engineering (IOSR-JMCE), eISSN: 2278-1684, p-ISSN: 2320-334X, July 2007

[11] Patel D. N., Pitroda J. R., "Techno Economical Development of Low-Cost Interlocking Paver Block By Partially Replacement of Portland Pozzolana Cement with Used Foundry Sand Waste", Journal of International Academic Research for Multidisciplinary, ISSN: 2320- 5083, Volume 2, Issue 4, May 2012

[12] Raja O. P.," Manufactured Sand can be Used as Fine Aggregate in Concrete Pavers, Block ”, International Journal of Engineering Research-Online (Ijer), ISSN: 2321-7758, Vol.2., Issue.6, December 2014

[13] Reddy M. A., "Temperature Effect of Various Bacteria Used in Microbial Concrete" International Journal of Innovative Research in Science, Engineering and Technology (IJIRSET), ISSN (Online): 2319-8753 / ISSN (Print): 2347-6710, Volume 5, Issue 4, April 2016

[14] Sudheesh C., Praveen Kumar T.R., Sasi Kumar S., "Effect of Compressive Strength on Concrete by Partial Replacement of Cement with Textile Sludge and Polypropylene Fibers", International Journal of Chemtech Research, ISSN: 0974-4290, Vol.8, Issue No: 4, 2015

[15] Vekariya M. S., Pitroda Jayeshkumar., "Bacterial Concrete: New Era for Construction Industry", International Journal of Engineering Trends and Technology (IJETT), ISSN: 2231-5381, Volume 4, Issue 9, Sep 2013

[16] IS 15658: 2006, Precast concrete blocks for paving- Specification

[17] IS 456:2000 Code of Practice for Plain and Reinforced Concrete

[18] IS 10262:2009 Guidelines for Concrete Mix Proportioning

[19] IRC:SP:63-2004 Guidelines for the Use of Interlocking Concrete Block Pavement

[20] IS 7245 : 1974 "Specification for concrete pavers"

\section{AUTHORS' BIOGRAPHY}



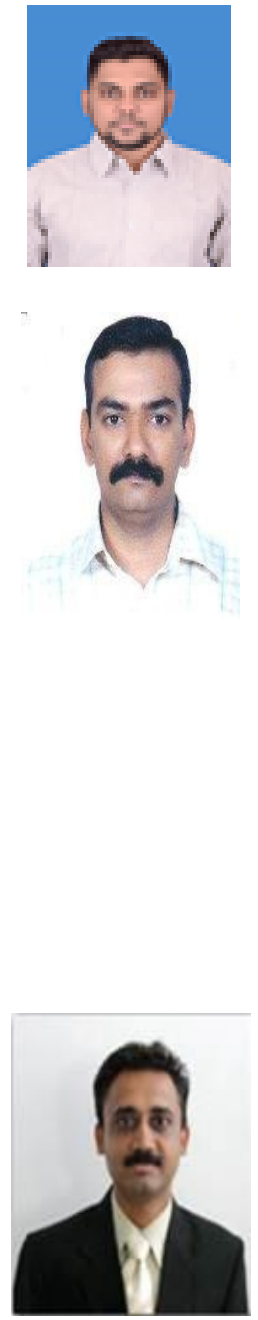

Sharma Maulik Arvindbhai, was born in 1990 in Kapadwanj Taluka of Kheda district, Gujarat. He has received his Bachelor of Engineering degree in Civil Engineering from the L.D Engineering College, Ahmedabad (GTU 1st batch) in 2012. At present, he is Final year student of Master's Degree in Construction Engineering and Management from Birla Vishwakarma Mahavidyalaya, Gujarat Technological University. He has published papers in international journals.

Dr. Jayeshkumar R Pitroda, received his bachelor of engineering degree in Civil Engineering from Birla Vishwakarma Mahavidyalaya Engineering College, Sardar Patel University in 2000. In 2009 he received his master's degree in Construction Engineering and Management from Birla Vishwakarma Mahavidyalaya Sardar Patel University. In 2015 he received his Doctor of philosophy (Ph.D.) degree in Civil Engineering from Sardar Patel University. He joined Birla Vishwakarma Mahavidyalaya Engineering College as a faculty in 2009, where he is Assistant Professor of Civil Engineering Department with a total experience of 16 years in the field of research, designing and education. He is guiding M.E. (Construction Engineering and Management) thesis work in the field of Civil / Construction Engineering. He has published many papers in National / International Conferences and International Journals. He has published seven Research Books in the field of Civil Engineering, Rural Road Construction, National Highways Construction, Utilization of Industrial Waste, Fly Ash Bricks, Construction Engineering and Management, Eco-friendly Construction.

Dr. Digvijaysinh Rana, completed his M.Sc. (2001) and Ph.D (2007) from Sardar Patel University, Vallabh Vidyanagar, and Gujarat. He has won the Gold medal for securing first position in M.Sc. Program of Sardar Patel University. Dr. Rana has more than 9 years of teaching and research experience. Dr. Rana is presently working as an Assistant Professor at Department of Integrated Biotechnology of ARIBAS (Ashok \& Rita Patel Institute of Integrated Study \& Research in Biotechnology and Allied Sciences) New Vidyanagar, Gujarat. Dr. Rana has taught Animal Cell Culture, Technology and Stem cells in Health Care for more than 9 years. Apart from teaching, he has also successfully established animal and parasite cell culture in ARIBAS for research purpose. He studies the biological, biochemical and molecular parameters of cultured cells. He had undergone trainings at Malaria Research Center (MRC-ICMR) for Plasmodium (Malarial parasite) culture and stem cell cultivation. $\mathrm{He}$ has been a mentor for more than 20 dissertation students of Integrated Biotechnology students. Dr. Rana received research grant from the Department of Science and Technology (DST). 